\title{
ROLLING BACK DEMOCRACY IN THE LATE SOEHARTO ERA: SOME IMPLICATIONS FOR INDONESIA'S POLITICAL CULTURE
}

Asian Studies Review, vol. 21, no. 2-3, pp. 53-66.

\author{
Ian Chalmers ${ }^{\mathrm{a}}$
}

Lecturer in Indonesian Studies and Southeast Asian Politics, Curtin University

On 27 July 1996 Indonesian politics was shaken by the most widespread riots to occur in the capital city for over twenty years. The leader of the opposition Indonesian Democratic Party (PDI), Megawati Sukarnoputri, had recently been overthrown from within her party in a government-engineered move. When she refused to bow to pressure and her supporters continued to occupy the PDI headquarters in central Jakarta, her opponents mounted a violent assault, and were actively aided by local sections of the Armed Forces. The forced removal of a popular opposition figure by state-backed armed thugs, leading to perhaps dozens of deaths, caused outrage to spill onto the streets. Crowds of youth and other protestors blocked roads, burned buildings, hurled stones at anyone in uniform, and for the following day played cat-and-mouse with the security forces sent to quell unrest. ${ }^{i}$

In the wake of the riots security forces rounded up and detained scores of political activists, and subjected Megawati's diverse band of supporters to sustained intimidation. Considerable press and scholarly attention has been given to these events and to the subsequent crackdown. Some have described this as a turning point in state-society relations, marking the end of a period of political 'openness' that had officially begun in 1989. It certainly provides evidence of a worrying degree of social alienation and high levels of political frustration, leading many proponents of democracy to despair of meaningful political change under the current leadership. Assuming that President Soeharto will be duly reelected, unopposed, during the five-yearly deliberations of the People's House of Assembly (MPR) in March 1998, most commentators have focused on the choice of a successor -particularly the Vice-President who would replace him should he suddenly retire, be incapacitated or be forced from office. ${ }^{\text {ii }}$ Although the selection of a candidate more open to the democratic imperative may lead to political reform, the issue of democracy goes far beyond the personality of Soeharto's successor, involving basic questions about political processes in Indonesia and the influences which shape them. In this article I wish to explore the implications of these events for the theorisation of Indonesian politics, making two propositions.

First, I suggest that we are inclined to underestimate the extent to which state power may be employed by the ruling group to quash dissent. In the article published in this journal in 1993, I predicted that liberalising tendencies would continue and that the government would treat political opponents with more tolerance; the advent of 'openness' indicated "an important shift in standard political discourse in Indonesia, perhaps heralding the emergence of a more liberal political culture". iii In retrospect, this picture was over-optimistic, for what 
we have witnessed since has been an erosion of the small gains that had been made. Rather than a growing diversity of elite opinion and continued liberalisation, political power remains concentrated around a president now more willing to use state authority arbitrarily. And rather than representing a sudden end to a timid experiment with liberalism, the 27 July incident and its aftermath should be seen as part of a longer-term tightening of political restrictions that has taken place since the early 1990s. Oppositional political groups remain very active, and are sometimes able to exploit tensions within the ruling elite, building links with parts of the state apparatus. But as illustrated below, opposition groups have been further excluded from institutionalised politics.

Second, I suggest that the non-responsiveness of political institutions in the context of popular dissatisfaction indicates a need for a broader mode of analysis. The preoccupation of scholars of Indonesian politics with either state institutions or class analysis has meant that those seeking to identify democratising forces underestimate the extent to which culture itself may shape political outcomes. In 1993 I argued that the expansion of the middle classes was the chief barrier to the broad democratisation of state institutions.

Should advocates of a more liberal political system succeed, it is plausible that this would open the way for new social forces to enter the institutions of state. But the interests of the expanding middle classes are increasingly tied to the emerging structures of Indonesian capitalism, and they are likely to oppose serious challenges to the status quo. What we are likely to see, therefore, is only a partial liberalisation, one that reinforces the economic interests and increases the political influence of Indonesia's urban middle classes. ${ }^{\text {iv }}$

Clearly, Indonesia's political rulers have been able to short-circuit the tentative liberalisation of the late 1980s and early 1990s. It is equally evident that the middle classes have not risen up in anger to prevent this from occurring. But below the surface of a state-dominated political system there is considerable disenchantment with official politics, an almost tangible desire for a new form of politics that may be laying the ideological basis for a more democratic form of governance. This dissatisfaction and its political manifestation can be understood best, I submit, through the lens of a political culture approach.

The Muffling of Overt Opposition in the 1990s

The calls for democratisation in Indonesia began to mount in the mid-1980s, when important sectors of the political elite began to advocate the open debate of sensitive issues. For various tactical reasons, a number of political groups called for changes in the existing political order under the slogan of political 'openness': members of parliament regretted the constraints on political parties; government leaders urged greater civilian political participation; even senior Armed Forces (ABRI) officers called for open debate in a more tolerant political climate. In mid-1990 Soeharto was obliged to acknowledge that open debate may be necessary to ensure future economic development. ${ }^{v}$

This liberalisation of debate coincided with an upsurge in public protest from nonelite sources, suggesting that the government's acceptance of diverse political opinion was 
also a tacit acknowledgement that it could not remove all dissent. Such protests have persisted. The acquisition of land designated for the development of private or state projects often results in demonstrations before parliament by poor squatters evicted from their shacks. Wild-cat strikes in the expanding manufacturing sector continue, as unrecognised and even illegal labour unions organise workers behind demands for improved working conditions. ${ }^{\mathrm{vi}}$ In sum, there is now more open criticism of decisions made by various levels of the government than has occurred since perhaps the mid-1970s.

Yet despite the government's frequent use of the rhetoric of democracy -- and its careful preservation of ostensibly democratic institutions -- such criticism has not been translated into tolerance of political opposition, as the attack on the PDI and its diverse supporters indicates. Tight restrictions have been placed on opposition forces, and, if the term 'openness' is used at all within the apparatus, it tends to be a slogan used by state officials to legitimise decisions already made rather than to encourage public participation and open debate. The expression of opposition opinion has thus been tightly corralled as part of the regime's strategy to defuse dissent and prevent the formation of organic links between popular protest and the political centre.

It has been suggested that the New Order government has totalitarian ambitions, and seeks to encompass all social activities within the embrace of state authority. ${ }^{\text {vii }}$ Yet these aspirations have never been fully realised, partly because Indonesia's oft-noted cultural and social diversity has mitigated against state control. A rather creaky state apparatus has also lessened the effectiveness of state intervention. The government has instead reinforced its authority using a corporatist strategy to control the articulation of political interests, attempting, on the one hand, to draw autonomous political forces into state-controlled organisations, while isolating potentially disruptive groups from the political process

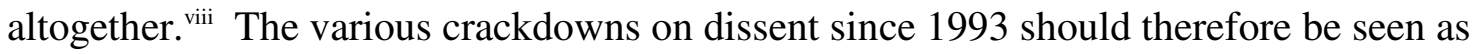
examples of the second element in the regime's corporatist strategy of cooption/isolation, of marking out the limits of legitimate debate to thereby prevent the institutionalisation of public protest.

Two cases will demonstrate the methods used to contain overt political opposition. In the first instance, in June 1994 the publication permits of three widely read weekly news publications were suddenly revoked. The ban placed on Tempo, Editor and Detik was the first large-scale action taken against the press since 1978, when over a dozen newspapers were banned following reports on anti-government demonstrations at national universities. Most observers were caught by surprise, for many had expected that, after almost three decades in power, the Soeharto government had become more tolerant of press criticism. Most readers had come to think of such journals, Tempo in particular, as an essential part of modern Indonesian society. The bans were followed by a number of demonstrations and howls of protest from certain media circles, but these actions failed to force a backdown. ${ }^{\text {ix }}$ 
The bannings certainly illustrate the regime's capacity to set the boundaries of legitimate debate. It was evidently journal's exposure of divisions within the government over development policy that drew Soeharto's anger, and was the immediate catalyst for the crackdown. ${ }^{\mathrm{x}}$ The case also shows the extent to which the regime will go to maintain its image of unity.

The second case involves the repercussions of the attack on the PDI. Megawati Sukarnoputri, daughter of the nation's first president, Sukarno, had in the previous few years considerably broadened the appeal of the PDI. By promoting earnest discussions on Indonesia's political future and holding open forums to encourage public debate, Megawati had begun to transform the PDI from the tame government-sponsored organisation it had been since its creation in 1973 into an arena for the expression of open political opposition. The success of the PDI in areas of Central and East Java during the 1992 election campaign was followed by Megawati's success in 1993 in winning party leadership, despite intense government pressure. Her success gave birth to a new term in the lexicon of Indonesian politics, arus bawah ('undercurrent' or 'grassroots'), which is now used to describe the mobilisation of mass support to oppose the leaders appointed by the ruling group, a phenomenon which stands in stark contrast to the political forms of the recent past. ${ }^{\mathrm{xi}}$

In a case closely related to the attack on the PDI, in mid-1997 a 27-year old prodemocracy activist, Budiman Sujatmiko, was convicted of fomenting subversion and was sentenced to thirteen years in jail; a dozen of his colleagues received similarly harsh sentences. The background to this development was the tightening of political restraints, for it was the effective marginalisation of Megawati's PDI from political life which led Budiman and his student colleagues to establish the 'People's Democracy Party' (PRD) as a channel for political opposition. The PRD now has been forced underground, but is still actively forging links with worker organisations. For the analysis presented here, the significance of the state response to the PDI's success and the formation of PRD is that it has cut the links between political protest and formal political representation.

It has also led to a resurgence of the anti-communist rhetoric that characterised the early years of the New Order. By more closely prescribing the limits to legitimate political debate, the Soeharto government has also restricted the expression of opposition within formal political institutions. A disturbing gap now exists between an official political culture, characterised by an emphasis on stability in order to promote economic development, and a deepening sense of popular distaste for an ageing regime. In such a situation, one in which a chasm yawns between state institutions and popular sentiment, realignments can come swiftly.

\section{The Democratisation of Authoritarian Regimes}

Perhaps the definitive element of democracy in modern states is the general acceptance of open political contestation as legitimate; democratisation thus entails the transition from a system in which opposition to the ruling group is considered treasonable, 
heretical or a threat to the unity of the nation, to one in which it is an everyday political event. In the period following the collapse of the authoritarian regimes of eastern Europe in the late 1980s, many other states have also successfully transformed their polities into democracies. In Latin America, there were few liberal democracies in the 1970s but, by the 1990s, most countries have functioning representative democracies. Liberal democracy has also taken hold in a number of military-ruled states in tropical Africa, while in the space of only a few years South Africa has undergone one of the most remarkable democratic transitions of the twentieth century. In Asia, countries as diverse as Nepal, Bangladesh, Taiwan, South Korea, Thailand and the Philippines have apparently and more or less successfully transformed authoritarian into democratic regimes, as initial hesitant experiments with liberal democracy have consolidated. Liberal democracy has thus become the common, almost archetypal, model for democratisation in a capitalist world system. ${ }^{\text {xii }}$

In this process, we can distinguish between an initial liberalisation and its subsequent consolidation. Most commonly, it is fragmentation of the ruling elite that encourages a liberalisation of debate that leads to the entry of new social forces into politics. Unable to control the situation as it had previously, the ruling elite is driven to form alliances with nonstate forces, gradually allowing a wider range of societal forces to become involved in political processes. Initially required to take into account the interests of different classes, the state eventually instititutionalises those interests within the political system. The consolidation of democracy thus entails the political participation of social forces which possess a strong interest in its survival. xiii $^{\text {in }}$

Within our region, such a model is applicable to the recent experience of Thailand. In the context of general dissatisfaction with the Suchinda regime and of widespread protest in 1992, the ruling military elite split. Different elements of the elite became allied with middle class and business forces anxious to restore political stability. The regime was forced to negotiate with the political representatives of these social groups, gradually opening the way for a return to the liberal democracy of the mid-1970s. ${ }^{\text {xiv }}$

Amongst students of Indonesian politics, the discourse on democratisation has revolved around the identification of potentially democratising social forces. Many look to the middle classes. Dan Lev has identified liberal sectors of the professional classes as the agent for democratisation. "A growing middle class is also likely to expand the number of reformers, especially among professionals, who will continue to raise questions about deeper change".. ${ }^{\mathrm{x}}$ Soetjipto Wirosardjono also predicts that the growth of the middle classes will limit state autonomy, and may provide the basis for the eventual triumph of civil society. ${ }^{\mathrm{xvi}}$ More recently, Ariel Heryanto has emphasised the emancipatory role that middle class reformers are likely to play. ${ }^{\text {xvii }}$ The common element to these accounts is the faith that middle class activists can play an instrumental role in subjugating state authority to social power.

Against this view, some have pointed out that the potential influence of the middle 
classes is constrained by their weak structural position within Indonesian society. Crouch suggests that the middle classes are still too small in number and too dependent on government patronage to challenge political structures. ${ }^{\text {xiii }}$ Richard Robison also argues that the lack of access to state institutions has also critically weakened the political influence of middle class elements.

It is little wonder, therefore, that middle class reformers have made such limited political progress in the past forty years. Internally divided, dependent upon the state and fearful of social and economic chaos they have been immobilised. The general assumption that middle classes represent sources of social power and wealth independent of the state and are therefore concerned with limiting its power and imposing accountability has not generally applied in Indonesia. ${ }^{\text {xix }}$

Others have gone further, arguing that it is the working class that has both the economic autonomy and political cohesion to constrain state authority and thereby advance democratisation. Vedi Hadiz, for example, finds evidence of a larger, more confident and more self-conscious working class movement that is beginning to force political reform. ${ }^{\mathrm{xx}}$ Mark Berger also makes the theoretical case that it has been working class movements that have generated democratic reforms, and suggests that the question of democracy in Indonesia therefore depends on the emerging urban proletariat rather than the middle classes. ${ }^{x i}$

The debate over whether it will be the working or middle classes who will deliver democracy is somewhat misplaced, however. In the first place, the privileging of a particular class is inappropriate in rapidly changing societies. Capitalist development is indeed associated with an expansion in both the size and political influence of the proletariat. However, in developing countries the working class is "far too weak to achieve by itself democratic rights for the subordinate classes... Alliances across class boundaries become critically important for the advance of democracy". xxii In Southeast Asia, the major political changes of recent decades have indeed been associated with such inter-class coalitions. In the Philippines, urban and rural workers undoubtedly provided the muscle that strengthened the anti-Marcos movements of the 1970s and 1980s, but it was NGOs staffed by middle class activists that provided the tactics and the organisation which preceeded the sudden collapse of the regime in 1986. ${ }^{\text {xiii }}$ In Thailand, workers provided the momentum that eventually forced the military regime to negotiate with the opposition in 1992, but here too middle class activists organised protests at a critical period. ${ }^{\text {xiv }}$ In both these cases it was the coalition of class interests that gave democracy movements their power.

In Indonesia, similarly, it has been political organisation across class lines that has provided the most potent challenges to the legitimacy of the New Order regime, and which has invoked the sharpest response. Long before the recent demonising of the PRD, other NGO groups involved in worker and peasant causes have come under close security surveillance. It is also likely that the attack on the PDI followed its success in marshalling both worker and business support. ${ }^{\mathrm{xxv}}$ 
A more fundamental reason for seeking to go beyond a focus on the articulation of class interests in the struggle for state power is that such analyses often overlook the extent to which political culture can shape political behaviour.

\section{Oppositional Politics and Indonesian Political Culture}

Political culture refers to the cultural values that influence political behaviour, and therefore the collective attitudes of a population toward the body politic in general. Originally popularised in the 1960s by American behavioural social scientist who sought to establish a link between the perceptions of individuals and a nation's political institutions, the concept came under considerable attack in the following decades as political scientists questioned its explanatory value. Many came to consider political culture an interesting but, ultimately, secondary aspect of political behaviour. However, three decades after Almond and Verba published their original study, The Civic Culture, political culture is again attracting interest. The apparent decline of many class-based movements, the resurgence of religious sentiment and the rise of nationalism worldwide has led political scientists to ask once more, to what extent do cultural factors determine political behaviour? ?xvi $^{2}$

The rediscovered version of political culture that has appeared in the last decade contains a fuller notion of political behaviour and the influences upon it, but its applicability in the context of the democratisation debate presents us with a major methodological issue. Clearly, political culture is not directly determinative of political behaviour, which is generally explicable by more tangible factors. But neither is it irrelevant, and some social scientists are prone to underestimate the resilience of cultural factors. In the case of rule by an authoritarian regime, the challenge is to try to establish the extent to which social and ideological values are shifting, perhaps presenting the government with long-term legitimacy problems.

Political scientists have long used a rather static formulation of political culture to account for Indonesian political behaviour. The New Order has often been characterised as statist, with decisions made autonomously by political leaders and implemented on behalf of a passive population. In some accounts, ideology and beliefs are virtually manufactured by the political leadership. ${ }^{\text {xxvii }}$ However, Indonesia's political culture is not monolithic, and opposition groups are able to manoeuvre within it to protect their interests. They often seek the support of particular state officials, and are constantly 'testing the water' to determine the limits of state tolerance towards criticism. They have had some successes, and the government has occasionally made significant concessions in the face of public opposition. In what Chua B.H. has called the 'politics of embarrassment,' opposition groups are sometimes able to employ official rhetoric to push their own demands. ${ }^{\text {xxviii }}$ In other words, opposition groups can occasionally create space within the framework of government's corporatist strategy to operate with some degree of autonomy. ${ }^{\text {xix }}$

More importantly, in a rapidly changing society alternative cultures are always 

political culture, Asian Studies Review 21(2-3):53-66.

available to opposition groups. William Liddle notes that for over half-a-century the middle classes in Indonesia have nurtured a distinct intellectual and artistic subculture, one never effectively integrated into the dominant national culture. This culture tends to be secular in outlook, more open to Western ideas, and more politically democratic; it is "an unofficial culture pushing for greater freedom and changes in many areas of social and cultural life".xx The significant point made by Liddle is that development-induced prosperity has eroded the social basis upon which the dominant culture is built. ${ }^{\mathrm{xxi}}$

A useful framework for describing the complex process of cultural and political change that Indonesia is undergoing is provided by the late Raymond Williams. Williams defines the dominant elements in a culture as the prevailing set of beliefs which give meaning to a particular social order and its institutions. In Indonesia, the dominant cultural elements are clearly related to developmentalism, namely the state-directed process of economic development. But for Williams the 'hegemonic process' of cultural and political construction is never static, for each culture contains within it elements that possess a source of signification beyond the cultural mainstream. He notes, for example, that there are always 'residual elements' that stand at some distance from the dominant culture: those experiences and activities given meaning by reference to a past dominant culture. Because of their independent source of signification, it is always possible for such concepts to constitute a counter-ideology, and the process of tradition-forming by state institutions has been most intense in the ideological incorporation of such residual elements.

In Indonesia, the most obvious residual cultural elements are those associated with her pre-colonial and nationalist past, and would include notions of village democracy, Javanese mysticism, as well as concepts associated with the nationalism of the pre-1965 period. Radical nationalist ideas associated with Article 33 of the 1945 Constitution, for example, are always available for reappropriation by critics of the current political order, and can therefore be considered active residual elements. Past criticism of New Order development strategies has largely been in such terms, criticising the government for failing to realise the goals of the 1945 revolution. .xxii $^{\text {xxi }}$

For the purposes of the argument presented here, the most relevant of Williams's categories is that of 'emergent' political cultures, the elements which bring about new meanings, values, practices and relationships in a society's cultural life. Williams considers the process of cultural change to be dialectical, an uneven process of breaks with tradition and efforts to absorb new ideas. The active forces in this process are what he calls 'formations', a broad category which includes both political institutions and intellectual movements. ${ }^{\text {xxiii }}$ The praxis of ideological transformation has, historically, been associated with the rise of new classes, and the distinguishing feature of the emergent is that it possesses a social basis for alternative and oppositional cultural forms. Existing institutions will attempt to either incorporate or delegitimise such values, but the initiatives of rising social forces cannot be coopted as easily as can those of residual elements. Real breaks can occur, perhaps leading to new forms of political and cultural discourse. 
The process of emergence...is then a constantly repeated, an always renewable, move beyond a phase of practical incorporation; usually made much more difficult by the fact that much incorporation looks like recognition, acknowledgment, and thus a form of acceptance. ${ }^{\text {xxiv }}$

The immediate relevance of Williams's perspective on ideological change is in accounting for the creeping acceptance in Indonesia of notions associated with political liberalism. Theorists note that as capitalism develops larger sectors of the middle class become involved in social reproduction, working as educators, professionals, journalists, artists and writers. This social change in turn introduces a new form of politics in which intellectuals play an enhanced role. ${ }^{\mathrm{xxx}}$ In Indonesia, this critical middle class has expanded rapidly in recent decades: growing sectors of the middle class are involved in media and communication industries; there has been a vast increase in the number of university graduates, particularly from private universities; hundreds of youth activists are still joining the NGO movement, evidently in increasing numbers; and perhaps most importantly, many of these graduates and middle class activists have found employment in journalism and other media-related activities, where they now possess the means to disseminate their views on a range of issues.

While the ideological effect of the growth of this middle class sector is necessarily somewhat intangible, it seems to have further enhanced the 'vital and dynamic alternative' political culture identified by Liddle. It seems clear from anecdotal evidence that the clampdown on press freedom has angered much of the largely middle class readership, and the closure of avenues of political expression has damaged the regime's legitimacy. Indonesia now has a more heterogenous political opposition with a stronger institutional base in society, one that is urging a broadening of democratic processes. ${ }^{\text {xxvi }}$ Conditions exist for the formation of cross-class alliances, while it is becoming increasingly difficult for a statedominated political culture to incorporate the resultant demands for political liberalisation.

\section{Conclusion}

Below the somewhat staid surface of official politics, Indonesian society is thus in a state of flux. The evident capacity of the government to prevent public protest has made opposition groups reluctant to challenge state authority openly; opposition circles recognise that the reform of state institutions might entail a lengthy process. Yet a sense of frustration persists, and even from within state structures there have been calls for the reform of political

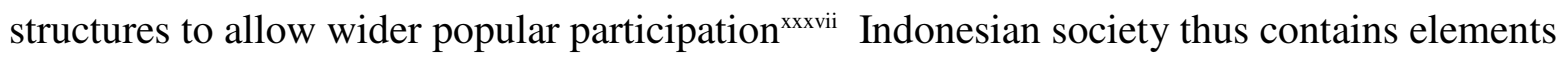
that can advance its emergent culture, the political form of which is liberal democracy. 
Chalmers, Ian (1997) Rolling back democracy in the late Soeharto era: some implications for Indonesia's political culture, Asian Studies Review 21(2-3):53-66. 


\section{ENDNOTES}

a For their comments on an earlier draft of this article, I would like to thank David Bourchier and colleagues in the Research Unit for the Study of Societies in Change (RUSSIC) in the School of Asian Studies and Asian Languages.

${ }^{i}$ According to reports by a number independent observers, the death count, officially put at five, actually numbered in the tens. This includes many activists said to have been killed during the attack on the PDI headquarters, during which others sustained serious injuries and required hospitalisation.

ii For a typical media account of the various contenders for the Vice-Presidency and their prospects, see 'Dicari Pemimpin Masa Depan' [Searching for a Future Leader], Forum Keadilan Special Edition, June 1997.

iii "Democracy Constrained: the Emerging Political Culture of the Indonesian Middle Classes," Asian Studies Review, Vol 17 No.1, 1993, p. 51.

iv ibid, p. 57.

v 'Presiden: Tidak Perlu Mengkhawatirkan Munculnya Berbagai Pemikiran' [The President: No Need to Fear the Rise of Diverse Ideas], Kompas 29 June 1990. This period is briefly described in Chalmers, op cit, p. 52, while Max Lane presents an optimistic account, typical of the time, of the democratic possibilities presented by the 'openness' episode: 'Openness', Political Discontent and Succession in Indonesia: 1989-1991 (Brisbane: Griffith University) Australia-Asia Paper no. 56.

${ }^{\text {vi }}$ Vedi Hadiz, 'Contradictions of Corporatism: Workers and the State in New Order Indonesia,' unpublished PhD thesis, Asia Research Centre, Murdoch University, Perth, 1996.

vii Richard Tanter, "The Totalitarian Ambition: Intelligence Organisations in the Indonesian State," in A. Budiman, ed., State and Civil Society in Indonesia (Clayton: Monash University) Papers on Southeast Asia no. 22, pp. 213-228.

viii The incorporation in the 1970s of trade unions, political parties, business associations and various other social organisations into distinct state-controlled bodies is best described by $\mathrm{M}$. Mas'oed, "The State Reorganisation of Society under the New Order," Prisma no. 47, 1989, pp. 3-24.

ix On the methods used by the New Order to control the press and the significance of "the anachronistic bans of the 1990s," see D. Hill, The Press in New Order Indonesia, Asia Paper no. 4 (Perth: University of WA Press), 1994, pp. 34-44. In late 1995 the editors of Tempo successfully appealed against the legality of the ban in the State Administrative Court (PTUN), but the government had this ruling overturned in the Supreme Court. 
${ }^{x}$ I. Chalmers and V. Hadiz (eds.), The Politics of Economic Development in Indonesia. Contending Perspectives (London and New York: Routledge), 1997, records the diversity of ideological perspectives on development in contemporary Indonesia, and pp. xxii-xxiv describes the specific controversy over development policy that preceeded the bans.

${ }^{x i}$ On Megawati's "miraculous success" in overcoming government pressure at the 1993 PDI congress and in galvanising the formation of the arus bawah, see Ariel Heryanto, "Indonesian Middle Class Opposition in the 1990s," in G. Rodan ed., Political Oppositions in Industrialising Asia, (London and New York: Routledge), 1996, pp. 241-271. B. King describes the reorganisation of PDI and its successes in the 1992 election: 'The 1992 General Election and Indonesia's Political Landscape," Contemporary Southeast Asia, Vol. 14, no. 2, 1992, pp. 154-173.

xii A large literature on the 'politics of transition' has emerged to describe this process, much of it celebrating the triumph of liberal democracy: L. Diamond, Political Culture and Democracy in Developing Countries (London and Boulder: Lynne Reiner); F. Fukuyama, The End of History and the Last Man (London: Hamish Hamilton).

xiii Adam Przeworski, "Some Problems in the Study of the Transition to Democracy", in G. O'Donnell, P. Schmitter and L. Whitehead (eds), Transitions from Authoritarian Rule: Comparative Perspectives (Baltimore and London: John Hopkins, 1986), pp. 47-63.

xiv Kevin Hewison, "Political Oppositions and Regime Change in Thailand," G. Rodan (ed.), Political Oppositions in Industrialising Asia (London and New York: Routledge), 1996, pp. $72-94$.

xv Daniel Lev, "Intermediate Classes and Change in Indonesia", in R. Tanter and K. Young (eds), The Politics of the Middle Class Indonesia (Melbourne: Centre of Southeast Asian Studies), 1990, p. 39.

xvi Soetjipto Wirosardjono, "Interpretation of the Current Scene," in D. Bourchier and J. Legge, eds., Democracy in Indonesia, 1950s and 1990s (Clayton: Monash University), pp. 243-247.

xvii Ariel Heryanto, “Indonesian Middle Class Opposition ..” op cit, 1996.

xviii Harold Crouch, "Democratic Prospects in Indonesia," in D. Bourchier and J. Legge, eds., Democracy in Indonesia, 1950s and 1990s (Clayton: Monash University), pp. 115-127.

${ }^{x i x}$ Richard Robison, "Indonesia: an Autonomous Domain of Social Power?," Pacific Review, vol 5 no. 4 , 1992 , p. 343.

${ }^{x x}$ Hadiz, 'Contradictions...' op. cit. 
${ }^{x x i}$ Mark T. Berger, "Old state and new empire in Indonesia: debating the rise and decline of Suharto's New Order,” Third World Quarterly, Vol 18, No 2, pp. 339-340, 353.

xxii Dietrich Rueschemeyer, Evelyne H. Stephens and John D. Stephens, Capitalist Development and Democracy (Cambridge, UK : Polity Press), 1992, p. 58

xxiii And support from sectors of business sectors -- most graphically demonstrated by the ticker-tape welcome for Aquino in the Makati business sector -- finally dissolved the legitimacy of regime. David Timberman, A Changeless Land (Singapore: ISEAS), 1991, pp. 150-155 discusses the various political forces behind the 'People's Power' events of 19831986. Anne-Marie Hilsdon, Madonnas and Martyrs (Sydney: Allen \& Unwin), 1995, pp. 152-158 describes the diversity of working, peasant and middle class political movements of the mid-1980s.

${ }^{x x i v}$ While the important role played by student and NGO activists was sometimes misleadingly translated into an image of a 'walkie-talkie revolution,' they did play a critical tactical role in organising the demonstrations and attracting media attention. See Hewison, op cit, pp. 83-85.

xxv The 1992 election was notable for the PDI's success in winning worker support in campaigns in rural and urban East Java and Central Java. The head of the PDI's Research and Development office is the well-known businessman and author, Kwik Gian Gie, who has become a prominent advocate of economic policy reform. See his Analisis Ekonomi Politik Indonesia (Jakarta: Gramedia), 1994.

xxvi One milestone in the concept's revival was the important debate between its proponents and critics published in G. Almond and S. Verba (eds.), The Civic Culture Revisited (London and Newbury Park: Sage), 1989. John Street provides an informative intellectual history of the concept. "Review Article: Political Culture - from Civic Culture to Mass Culture", British Journal of Political Science, Vol. 24, 1993 pp. 95-114. See also John Gibbins (ed.), Contemporary Political Culture (London, Delhi and Newbury Park: Sage), 1989.

xxvii. The standard description of New Order ideological construction is the rather pessimistic account of Michael Morfit, "Pancasila: the Indonesian State Ideology according to the New Order Government," Asian Survey, Vol 21 no. 8, 1981, pp. 838-851. A more recent formulation along these lines is that of C. Watson, "P4: the Resurrection of a State Ideology in Indonesia," in State and Society in Indonesia - Three Papers (Canterbury: University of Kent), 1988. See also John Bowen, "On the Political Construction of Tradition: GotongRoyong in Indonesia,” Journal of Asian Studies, vol. 44 No. 3, pp. 545-561. For a more nuanced account of how the various elements of the national political culture are manipulated and redefined according to the needs of the current leadership, see David Bourchier, 'Lineages of Organicist Political Thought in Indonesia,' Phd thesis, Politics, Monash University, 1996. 
xxviii Chua Beng Huat, "Looking for Democratization in Post-Soeharto Indonesia," Contemporary Southeast Asia, Vol. 15 No. 2, 1993, pp. 152-154.

xxix. Perhaps the best example of this tactic involves the Nahdlatul Ulama (NU), a Muslim organisation led by the wily politician, Abdurrachman Wahid, who has managed to maintain NU's political influence by offering selective and qualified support to the regime at critical junctures.

xxx R.W. Liddle, Politics and Culture in Indonesia (Ann Arbor: University of Michigan), pp. 23-24.

xxxi ibid, p. 31.

xxxii Article 33 is often upheld as the most 'socialist' clause in the 1945 Constitution, and declares that the state will control important sectors of the economy to advance the common good. It has often been employed by representatives of such a counter-tradition, which would include people like Moh. Hatta, Mubyarto, Sri-Edi Swasono and, perhaps, Adi Sasono. Chua B.H., "Looking for Democracy..." op. cit., also notes the traditionalist nature of much 'radical' internal criticism of the New Order.

xxxii Raymond Williams, Marxism and Literature (Oxford: Oxford University Press), 1977, p. 117.

xxxiv ibid, pp. 124-125.

xxxv N. Abercrombie and John Urry, Capital, Labour and the Middle Classes (London: Allen \& Unwin), 1983.

xxxvi Edward Aspinall, "The Broadening Base of Political Opposition in Indonesia," G. Rodan ed., Political Oppositions in Industrialising Asia (London and New York: Routledge), 1996 pp. 215-240, describes the more heterogenous forms of opposition movements in the 1990s. He sees the beginnings of their institutionalisation through NGO movements.

xxxvii One example is the proposal made by various political commentators and even researchers in the governments Institute of Sciences to limit the Presidential office to two terms. See 'Kelak, Presiden Cukup Dua Kali Saja' [Later, Twice for the President will be Enough], Forum Keadilan 22 Sep 1997, pp. 106-107. 